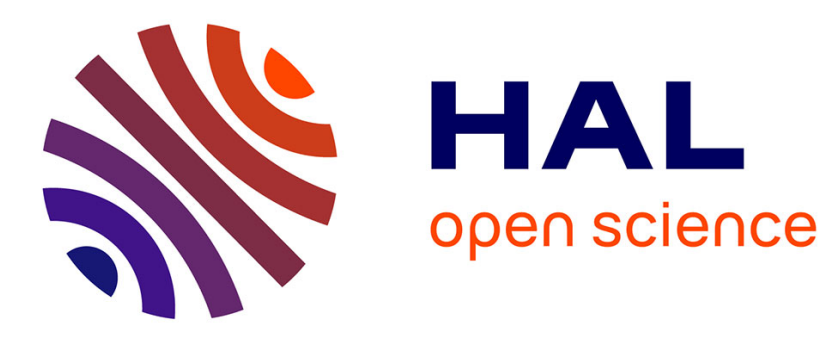

\title{
Synthesis, characterization, and antileishmanial activities of gold(I) complexes involving quinoline functionalized N-heterocyclic carbenes
}

Lucie Paloque, Catherine Hemmert, Alexis Valentin, Heinz Gornitzka

\section{- To cite this version:}

Lucie Paloque, Catherine Hemmert, Alexis Valentin, Heinz Gornitzka. Synthesis, characterization, and antileishmanial activities of gold(I) complexes involving quinoline functionalized N-heterocyclic carbenes. European Journal of Medicinal Chemistry, 2015, 94, pp.22-29. 10.1016/j.ejmech.2015.02.046 . hal-01925132

\section{HAL Id: hal-01925132 \\ https://hal.science/hal-01925132}

Submitted on 21 May 2021

HAL is a multi-disciplinary open access archive for the deposit and dissemination of scientific research documents, whether they are published or not. The documents may come from teaching and research institutions in France or abroad, or from public or private research centers.
L'archive ouverte pluridisciplinaire HAL, est destinée au dépôt et à la diffusion de documents scientifiques de niveau recherche, publiés ou non, émanant des établissements d'enseignement et de recherche français ou étrangers, des laboratoires publics ou privés. 


\section{Synthesis, characterization, and antileishmanial activities of gold(I) complexes involving quinoline functionalized $N$-heterocyclic carbenes}

Lucie Paloque, ${ }^{a, b}$ Catherine Hemmert, ${ }^{* c, d}$ Alexis Valentin, ${ }^{a, b}$ Heinz Gornitzka ${ }^{c, d}$

a Université de Toulouse; UPS; UMR 152 Pharma-DEV; Université Toulouse 3; Faculté des sciences pharmaceutiques; 35 Chemin des maraîchers, F-31062 Toulouse cedex 9, France.

b Institut de Recherche pour le Développement; IRD; UMR 152 Pharma-DEV, F-31062 Toulouse cedex 9, France.

c CNRS, LCC (Laboratoire de Chimie de Coordination), 205 route de Narbonne, BP 44099, F-31077 Toulouse Cedex 4, France.

d Université de Toulouse, UPS, INPT, F-31077 Toulouse Cedex 4, France.

*Corresponding Author. Tel.: +33 561553187; fax: +33 561553003.

E-mail address: hemmert@1cc.toulouse.fr; 


\begin{abstract}
A series of new mononuclear cationic or neutral gold(I) complexes containing quinoline functionalized $N$-heterocyclic carbene(s) (NHC(s)) were synthesized and fully characterized by spectroscopic methods. The X-ray structures of two key compounds are presented. Proligands and their corresponding gold(I) complexes together with previously described silver(I) and gold(I) bis(NHC-quinoline) and gold(I) bis(NHC-methylbipyridine) complexes were evaluated in vitro towards Leishmania infantum. In parallel, the in vitro cytotoxicity of these molecules was assessed on the murine macrophages J774A.1. All gold(I) compounds show potent antileishmanial activity against $L$. infantum promastigotes and three of them are also efficient against $L$. infantum intracellular amastigotes. Structure-activity and toxicity relationships enables to evidence a lead-compound (6) displaying both a high activity and a good selectivity index.
\end{abstract}

Keywords: gold, $N$-heterocyclic carbene, quinoline, Leishmania infantum, J774.1A, antileishmanial activity.

\title{
1. Introduction
}

The Leishmania parasite is transmitted in their promastigote form to the mammalian host by the bite of infected sandflies (Phlebotominae) during their blood meal. Then promastigotes target cells of the immune system, macrophages and dendritic cells, where they differentiate into amastigotes forms, living inside the digestive vacuole of these host cells, responsible for leishmaniasis. Among tropical diseases, leishmaniasis remains one of the most neglected in terms of available controls and affects more and more countries. In 2007 this parasitic disease was endemic in 88 countries, in 2012 in 98 countries (mainly in tropical and sub-tropical regions, but also in southern Europe, especially around the Mediterranean area), and the number of cases continues to increase still certainly underestimated because reporting of this disease is mandatory in only 33 of the 98 countries involved. Factors and/or events such as mass migration of non-immune populations, deteriorating of socio-economic conditions and increase of immune-deficient people also lead to a resurgence of leishmaniasis worldwide. Actually this disease affects every year an estimated 1.3 million people and is the second most lethal parasitic infection worldwide with about 50.000 annual deaths. Leishmaniasis symptomatology may range from visceral disease affecting the haemopoetic organs, to 
cutaneous and muco-cutaneous lesions that may cause disfiguring destruction of mucous membranes [1,2]. Until now, there is no available vaccine for humans whereas dogs can be preventively treated by the CaniLeish ${ }^{\circledR}$ (Europe), Leishmune ${ }^{\circledR}$ or Leish-Tec ${ }^{\circledR}$ (Brazil) vaccines $[3,4]$. In human medicine, very few drugs are available: pentavalent antimonials, liposomal amphotericin B, pentamidine, paromomycin, miltefosine. Sitamaquine and Fexinidazole are the only new ones actually in phase II clinical trial $[5,6]$. These drugs present main limitations including non-oral routes of administration (except for miltefosine), very expensive cost of liposomal amphotericin B (making this last drug unaffordable for most of affected patients), teratogenicity of miltefosine (prohibiting its use in many women) and finally, severe adverse effects of both pentamidine and pentavalent antimonials, leading to patients withdrawing from treatments and emergence of resistant strains. In this context, novel, effective, and safe drugs having reduced side effects in their treatment regimens against Leishmania is a major priority for health researchers [1].

Numerous synthetic organic compounds, including quinoline derivatives, that showed antileishmanial activities equal to or better than those of the standard drugs have been recently reviewed [7-11]. On the other side, advancements in the rational design of metal-based therapeutic agents have increased after the important discovery of cisplatin, and its derivatives as anticancer drugs [12,13], which has been the main impetus for the expansion of metal complexes in cancer and other pathologies. The peculiar biological properties of some organometallic compounds have helped in the development of new drugs based on metal complexes for major medical human problems including mainly cancer along with bacterial, viral and parasitic diseases [14]. In particular, the similarity between metabolic pathway of Leishmania parasites and tumor cells [15] and the fact that many antiprotozoal drugs bind to DNA, has led to the use of transition metal complexes as metallointercalators. Iridium, ruthenium, gold, copper, platinum and rhodium complexes with organic drugs or metallointercalating ligands are examples that have been explored for their antileishmanial activity [16-18]. However, there are just few gold based compounds explored against leishmaniasis [19].

Very recently, we focused our research on heteroditopic $\mathrm{N}$-heterocyclic carbene (NHC) gold(I) complexes for their biomedical potential in anticancer and parasitic diseases such as malaria [20,21]. In particular, we have previously shown that mononuclear cationic gold(I) complexes containing aromatic amino-functionalized NHC exhibit in vitro potent and non toxic antiplasmodial activity against the chloroquino-resistant strain FcM29-Cameroon with 
$\mathrm{IC}_{50}$ values up to $330 \mathrm{nM}$ [20]. In this work, we report the preparation and characterization of three mononuclear gold(I) complexes involving quinoline-NHC ligands. A family of molecules, based on aromatic nitrogen containing NHCs and including proligands and mononuclear group 11 complexes, was evaluated both for their in vitro antiprotozoal activity toward L. infantum promastigotes and their in vitro cytotoxicity on J774.1 murine macrophages. Moreover, the most selective ones were tested for their in vitro activity toward Leishmania intracellular amastigotes.

\section{Results and discussion}

\subsection{Chemistry}

\subsubsection{Synthesis of quinoline functionalized imidazolium salts}

The imidazolium salt 1 was prepared from commercially available reagents, by heating an excess of 1-methylimidazole and 2-chloroquinoline in toluene (Scheme 1). 1-(4Methylthiophenyl)- $1 H$-imidazole was efficiently synthetized by a copper-catalyzed $\mathrm{N}$ arylation of imidazole with 4-bromothioanisole in the presence of $\mathrm{K}_{2} \mathrm{CO}_{3}$ at $205{ }^{\circ} \mathrm{C}$ without solvent. The proligands $\mathbf{2}$ and $\mathbf{3}$ were simply obtained after a quaternization step of 1arylimidazole (aryl = mesityl for $\mathbf{2}$ and methylthiophenyl for $\mathbf{3}$ ) with one equivalent of 2chloroquinoline at $170{ }^{\circ} \mathrm{C}$ whitout solvent (Scheme 2). The most notable features in the ${ }^{1} \mathrm{H}$ and ${ }^{13} \mathrm{C}$ NMR spectra of the imidazolium salts are the resonances for imidazolium protons $\left(H_{2}\right)$ located at $10.89,12.17$ and $11.02 \mathrm{ppm}$ and the corresponding imidazolium carbons $\left(\mathrm{C}_{2}\right)$ in the range of 135.2-137.8 ppm, for $\mathbf{1}, \mathbf{2}$ and $\mathbf{3}$ respectively. The mass (FAB) or high resolution mass (ES) spectra of all compounds exhibit the classical peak corresponding to [M $-\mathrm{Cl}]^{+}$cations.

Scheme 1. Synthesis of imidazoliums salts $\mathbf{1}$ and 1' and silver(I) bis(NHC) (4), gold(I) bis (NHC) (5)and gold(I) NHC (6) complexes.

Scheme 2. Synthesis of imidazoliums salts $\mathbf{2}$ and $\mathbf{3}$ and gold(I) bis (NHC) complexes $\mathbf{7}$ and $\mathbf{8}$.

\subsubsection{Synthesis and characterization of mononuclear gold(I) complexes}

The synthesis of gold(I) as well as silver(I) bis(NHC) complexes were previously described [20]. We have chosen the convenient transmetalation route to prepare the neutral gold(I) complex 6. Firstly, the silver precursor complex was prepared by deprotonation of the 
imidazolium salt 3 , with an excess of the mild base $\mathrm{Ag}_{2} \mathrm{O}$ in acetonitrile at $40{ }^{\circ} \mathrm{C}$. The carbene transfer reaction was then carried out in situ, by adding one equivalent of $\mathrm{Au}\left(\mathrm{SMe}_{2}\right) \mathrm{Cl}$, with respect to the ligand. The cationic mononuclear gold(I) complexes $\mathbf{7}$ and $\mathbf{8}$ were prepared according a classical way, from the $N$-functionalized imidazolium salts $\mathbf{2}$ or $\mathbf{3}$ and one half equivalent of $\mathrm{Au}\left(\mathrm{SMe}_{2}\right) \mathrm{Cl}$ with sodium acetate as a mild base in hot $\mathrm{N}, \mathrm{N}$-dimethylformamide $\left(120^{\circ} \mathrm{C}\right)$. Gold(I) complexes 6-8 were isolated as white or beige powders with good yields (74-85\%); all the synthesized complexes are highly stable towards air and moisture and soluble in $\mathrm{CH}_{3} \mathrm{CN}, \mathrm{MeOH}, \mathrm{H}_{2} \mathrm{O}$ and DMSO. NMR spectroscopy unequivocally demonstrates the formation of the gold(I) complexes; the ${ }^{13} \mathrm{C}$ spectra show the resonance for the carbene carbon atoms at $170.1,181.4$ and 180.8 ppm, for $\mathbf{6 , 7}$ and $\mathbf{8}$, respectively. These values are in the range of reported values for $\mathrm{Au}^{\mathrm{I}}-\mathrm{NHC}$ complexes having $\mathrm{C}-\mathrm{Au}-\mathrm{X}(\mathrm{X}=$ halide $)$ or $\mathrm{C}-\mathrm{Au}-\mathrm{C}$ motifs [22]. The elemental analysis of the gold(I) complexes correspond to the general formula $\mathrm{AuLCl}$ for $\mathbf{6}$ and $\left[\mathrm{AuL}_{2}\right][\mathrm{Cl}]$ for $\mathbf{7}$ and $\mathbf{8}$ and the high resolution mass spectra (ES) exhibit the classical peaks corresponding to the cationic fragments $[\mathrm{M}+\mathrm{H}]^{+}$for the neutral complex $\mathbf{6}$ and $[\mathrm{M}-\mathrm{X}]^{+}$for the cationic compounds $\mathbf{7}$ and $\mathbf{8}$.

\subsubsection{Crystal structures of complexes 6 and 7}

Crystals of 6 suitable for X-ray diffraction analysis were obtained by slow evaporation from an acetonitrile solution of this compound (see Figure 1).

Figure 1: Crystal structure of 6 depicted at 50\% level. Hydrogen atoms have been omitted for clarity. Selected bond lengths $[\AA]$ and angles $\left[{ }^{\circ}\right]$ : Au-C 1.96(2), Au-Cl 2.28(1), C-Au-Cl 177.3(6).

In the case of 7, slow evaporation from a methanolic solution led to crystals suitable for $\mathrm{X}$-ray diffraction analysis (see Figure 2).

Figure 2: Crystal structure of the cationic part of 7 depicted at 30\% level. Non-coordinating anions and hydrogen atoms have been omitted for clarity. Selected bond lengths [^] and angles [ ${ }^{\circ}$ ]: Au-C1 1.997(6), Au-C22 2.016(6), C1-Au-C22 178.9(2). 
In both structures the gold atom is coordinated in a classical linear manner for gold(I) compounds. The gold carbon distances are in the normal ranges for $\mathrm{NHC}-\mathrm{Au}-\mathrm{Cl}$ and $\mathrm{NHC}-$ $\mathrm{Au}-\mathrm{NHC}$ compounds. It is notable that in both cases the nitrogen atoms of the quinoline systems are localized away from the gold atoms and that the quinoline rings systems are not coplanar with the NHC ring systems (C-N-C-N $=148^{\circ}$ for 6 and $127-137^{\circ}$ for 7$)$.

\subsection{Biological activity}

Figure 3. Compounds $\mathbf{9}$ and $\mathbf{1 0}$ also used in this study. ${ }^{\mathbf{9}}$

All molecules 1-10 were first screened in vitro on the promastigote stage of $L$. infantum by determining their inhibitory concentrations $50 \% \quad\left(\mathrm{IC}_{50}\right)$ and compared to different antileishmanial reference-drugs: amphotericin $\mathrm{B}$, miltefosine and pentamidine. In order to assess their selectivity of action, all molecules were also evaluated in vitro as regards of their cytotoxicity, measured by the cytotoxic concentrations $50 \%\left(\mathrm{CC}_{50}\right)$ on the murine $\mathrm{J774A} .1$ macrophages cell line (positive control $=$ doxorubicin), giving access to the corresponding selectivity indexes $\left(\mathrm{SI}=\mathrm{CC}_{50} / \mathrm{IC}_{50}\right)$. The most selective compounds were then screened on the intracellular amastigote stage of $L$. infantum, the pathological relevant form of Leishmania.

Except proligands 1, 1' and 9, all tested compounds including imidazolium salts, mononuclear silver(I) and gold(I) complexes presented an antileishmanial $\mathrm{IC}_{50}$ lower than 15 $\mu \mathrm{M}$ against promastigotes of $L$. infantum. The carbene precursors $\mathbf{2}$ and $\mathbf{3}$ exhibited relatively good antileishmanial $\mathrm{IC}_{50}$ values of 9.81 and $11.96 \mu \mathrm{M}$ but they can only be considered as globally aspecific toxic molecules because of their very low $\mathrm{CC}_{50}$ values. First informations concerning the organic cationic proligands are emerging from these results. All imidazolium salts comprise an aromatic nitrogen containing arm, namely a quinoline moiety $(\mathbf{1}, \mathbf{1}, 2$ and 3) or a methyl-bipyridine entity (9), but differ in their non functionalized groups, methyl or aryl (mesityl for $\mathbf{2}$ and methylthiophenyl for $\mathbf{3}$ ). The highest lipophilicity of $\mathbf{2}$ and $\mathbf{3}$ correlates with the higher antiproliferative activity against promastigotes, when compared to methylsubstituted imidazoliums (1, 1' and 9), a trend that we have already demonstrated in anticancer investigation of gold(I) aliphatic amino-NHCs complexes [21]. The silver(I) bis(NHC) complex (4) showed a potent but poorly specific antiprotozoal activity with respect 
to the starting proligand 1', with an $\mathrm{IC}_{50}$ value of $9.37 \mu \mathrm{M}$ and a selectivity index of 1.61 . The antileishmanial activity of the corresponding gold(I) complexes 5-8 and $\mathbf{1 0}$ was highly improved when compared to the corresponding proligands, with $\mathrm{IC}_{50}$ in the micromolar and submicromolar range, from 0.39 to $1.86 \mu \mathrm{M}$. The best values on Leishmania promastigotes were obtained for the three cationic $\mathrm{Au}(\mathrm{I})$ bis(NHC-quinoline) species with $\mathrm{IC}_{50}$ of $0.39,0.42$ and $0.43 \mu \mathrm{M}$ for $\mathbf{5 , 7}$ and $\mathbf{8}$, respectively. Moreover as regards the toxicity, while the complex 7 appears to be non selective $\left(\mathrm{CC}_{50}=0.61\right)$ although it is less toxic than the starting imidazolium salt $2\left(\mathrm{CC}_{50}=0.09\right)$, compounds 5, 6 and $\mathbf{8}$ exhibit interesting selectivity index comprised between 3.02 and 6.19. From these initial results, the later three complexes were selected for additive assays on the intracellular amastigote stage of L. infantum, in order to estimate the real potential of these organometallic molecules as efficient and selective antileishmanial compounds. They all display good antileishmanial activity on intracellular amastigotes with $\mathrm{IC}_{50}$ values below $1 \mu \mathrm{M}$, the best value being $0.24 \mu \mathrm{M}$ for 8 . More interestingly, the neutral complex 6 stands out with a selectivity index near to 10 (9.84). This compound display an anti promastigotes activity 38 times and 3 times higher than the one of amphotericin B and pentamidine respectively, but 5.8 times lower than the one of miltefosine, and an anti asmastigotes activity 4.3 times lower than the one of miltefosine also. Overall, structure-activity relationships can be brought out for this family of gold complexes. First, this set of results evidenced the key role of the gold cation in antiprotozoal activity against $L$. infantum promastigotes and intracellular amastigotes. In this case, it seems that the carbenic ligand acts mainly as a carrier for the metal center towards its target(s). Second, even if the efficiency of compounds 5-8 and $\mathbf{1 0}$ are in the same order, the charge of the complex constitutes an important factor for the selectivity and the neutral gold complex $\mathbf{6}$ can be considered as the hit molecule in this study. To the best of our knowledge, the herein tested complexes represent the first examples of gold(I) functionalized NHC with efficacious antileishmanial activity.

In general, with the exception of antimonials, the use of metallodrugs and especially gold compounds as antileishmanial agents was scarcely explored and warrants deeper insight to elucidate molecular targets and modes of action. From the literature, Colotti and co-workers evaluated the antiarthritic gold(I) drug auranofin and $\left[\mathrm{AuCl}\left(\mathrm{PEt}_{3}\right)\right]$ (PEt: triethylphosphine) as antileishmanial agents [23]. Tests in vitro showed activity on the promastigote stage of $L$. infantum with $\mathrm{IC}_{50}$ of 9.68 and $16.59 \mu \mathrm{M}$, respectively. Because gold(I) compounds are known to be highly thiophilic, the authors have performed enzymatic assays on trypanothione 
reductase (TR), which contains a dithiol motif in its active site; they have demonstrated that both auranofin and $\left[\mathrm{AuCl}\left(\mathrm{PEt}_{3}\right)\right]$ cause a pronounced inhibition of TR, a key enzyme of $L$. infantum polyamine-dependent redox metabolism and a validated target for antileishmanial drugs. Navarro et al. reported a gold(III) complex, containing a DNA intercalating dppz ligand (dppz: dipyrido[3,2-a:2',3'-c]-phenazine) able to induce dose-dependent antiproliferative activity against promastigotes of $L$. mexicana with a minimal inhibitory concentration (MIC) of $3.4 \mathrm{nM}$ and a lethal dose $\left(\mathrm{LD}_{26}\right)$ of $17 \mathrm{nM}$ for $48 \mathrm{~h}$. DNA interaction studies showed that this gold(III) complex may interact with calf thymus DNA and plasmid pUC 119, so the authors proposed that the potent leishmanicidal activity may be associated to the interaction of this gold-dppz compound with the parasite DNA by intercalation mode [24]. The same authors reported also a proposed dinuclear gold(I) triphenylphosphine complex with the bioactive coligand pyridine-2-thiol $N$-oxide (mpo). This compound showed in vitro potent activity against promastigotes of L. mexicana and L. braziliensis and Trypanosoma. cruzi epimastigotes and low unspecific cytotoxicity on mammalian macrophages. The coordination of gold to mpo induced a potentiation of the antiproliferative effect against both Leishmania species and T. cruzi, which could be associated to the inhibition of NADH fumarate reductase absent in mammalian cells [25]. The antiprotozoal activity and proposed or supposed targets of gold complexes confirms the strong interest to develop and study new gold-based molecules as antileishmanial compounds. Within this framework, the next step of our work will be the pharmacomodulation of our lead compound $\mathbf{6}$ by fine tuning either the nonfunctionalized group (alkyl or aryl) or/and the quinoline entity, in order to improve both activity and selectivity in particular toward intracellular amastigotes forms of Leishmania, and afterwards to understand the mechanism(s) of action of these new promising gold(I) functionalized NHC metallodrugs and to study their in vivo activity on murine model.

\section{Conclusion}

A new family of compounds, namely five imidazoliums salts, one silver(I) and five gold(I) complexes based on aromatic nitrogen functionalized NHCs and including six new synthetized and fully characterized ones, was screened in vitro for its antileishmanial activity against both the promastigote and the intramacrophagic amastigote forms of L. infantum. Moreover, the cytotoxicity was assessed on the murine J774A.1 macrophages, in order to determine their selectivity of action. From this studies, gold(I) NHC-quinoline and in particular a neutral complex proved to be promising metallodrugs with potent and selective 
action against the pathological relevant form of Leishmania. By taking into account that 1) quinoline derivatives are one of the most studied families of organic compounds for leishmanicidal activity evaluation (due to their easily modulable scaffold) and 2) gold(I) complexes are good candidates for parasitic pathogens such as Leishmania, we aim to develop further synergetic metal-drugs based on $\mathrm{Au}(\mathrm{I})-\mathrm{NHC}$ and quinolines or aminoquinolines derivatives, easy to set up and with high pharmacological activity and low toxicity.

\section{Experimental section}

\subsection{General Information}

Unless otherwise stated, all reactions were performed in air. All reagents were used as received from commercial suppliers. 1-Mesitylimidazole [26], 3-Methyl-1-(quinolin-2-yl)1H-imidazol-3-ium hexafluorophosphate (1'), 3-Methyl-1-\{[6-(pyridin-2-yl)pyridin-3yl]methyl $\}-1 H$-imidazol-3-ium bromide (9) and complexes 4, 5 and 10 [20] were prepared according literature procedure. Reactions involving silver compounds were performed with the exclusion of light. ${ }^{1} \mathrm{H}$ (300 or $400 \mathrm{MHz}$ ) and ${ }^{13} \mathrm{C}$ NMR spectra (75 or $101 \mathrm{MHz}$ ) were recorded at $298 \mathrm{~K}$ on Bruker $\mathrm{AV} 300$ or Bruker AV400 spectrometers in $\mathrm{CDCl}_{3}, \mathrm{CD}_{3} \mathrm{OD}$, $\mathrm{CD}_{3} \mathrm{CN}$ as solvents. Elemental analyses were carried out by the "Service de Microanalyse du Laboratoire de Chimie de Coordination (Toulouse). Mass spectrometry analysis were performed on a Nermag R1010 (FAB ${ }^{+} /$meta-nitrobenzylalcohol (MNBA)) spectrometer and HRMS were performed with a Thermo Finnigan MAT 95 XL spectrometer using electrospray ionization (ESI) by the "Service de Spectrométrie de Masse de Chimie UPS-CNRS" (Toulouse).

\subsubsection{Preparation of imidazolium salts}

Scheme 3. Numbering of $\mathrm{H}\left({ }^{1} \mathrm{H}\right.$ NMR) and $\mathrm{C}\left({ }^{13} \mathrm{C}\right.$ NMR $)$. These notations are used in the following experimental section.

\subsubsection{3-Methyl-1-(quinolin-2-yl)-1H-imidazol-3-ium chloride (1)}

1-Methylimidazole (3.2 $\mathrm{mL}, 40.22 \mathrm{mmol})$ and 2-chloroquinoline (1.88 g, $11.49 \mathrm{mmol})$ were stirred in toluene $(6 \mathrm{~mL})$ in a closed pressure tube at $130{ }^{\circ} \mathrm{C}$ for $24 \mathrm{~h}$. After cooling to room temperature, the solvent was evaporated and the resulting brown paste was triturated with acetone and diethyl ether successively. The beige solid obtained was filtered and dried under 
vacuum (1.455 g, 52\% yield). Anal. Calcd. For $\mathrm{C}_{13} \mathrm{H}_{12} \mathrm{~N}_{3} \mathrm{Cl}$ : C, 63.55; H, 4.92; N, 17.10. Found: C, 63.38; H, 5.02; N, 17.03. ${ }^{1} \mathrm{H}$ NMR (400 MHz, $\left.\mathrm{CD}_{3} \mathrm{CN}\right) \delta 10.89\left(\mathrm{~s}, 1 \mathrm{H}, H_{2}\right), 8.64$ $\left(\mathrm{d}, J=8.8 \mathrm{~Hz}, 1 \mathrm{H}, H_{8}\right), 8.44\left(\mathrm{t}, J=1.9 \mathrm{~Hz}, 1 \mathrm{H}, H_{5}\right), 7.31\left(\mathrm{~d}, J=8.8,1 \mathrm{H}, H_{7}\right), 8.11-8.03(\mathrm{~m}$, $\left.2 \mathrm{H}, H_{10}, \mathrm{H}_{13}\right), 7.90\left(\mathrm{ddd}, J=8.4,6.9,1.5 \mathrm{~Hz}, 1 \mathrm{H}, H_{12}\right), 7.73(\mathrm{ddd}, J=8.2,6.9,1.2 \mathrm{~Hz}, 1 \mathrm{H}$, $\left.H_{11}\right), 7.67\left(\mathrm{t}, J=1.9 \mathrm{~Hz}, 1 \mathrm{H}, H_{4}\right), 4.10\left(\mathrm{~s}, 3 \mathrm{H}, \mathrm{C} H_{3}\right) .{ }^{13} \mathrm{C} \mathrm{NMR}\left(101 \mathrm{MHz}, \mathrm{CD}_{3} \mathrm{OD}\right) \delta 146.0$ (1C, $\left.C_{6}\right), 144.8\left(1 \mathrm{C}, C_{14}\right), 141.1\left(1 \mathrm{C}, C_{8}\right), 135.5\left(1 \mathrm{C}, C_{2}\right), 131.3\left(1 \mathrm{C}, C_{12}\right), 128.3\left(1 \mathrm{C}, C_{13}\right)$, $128.0\left(1 \mathrm{C}, C_{10}\right), 127.8\left(1 \mathrm{C}, C_{9}\right), 127.8\left(1 \mathrm{C}, C_{11}\right), 124.6\left(1 \mathrm{C}, C_{7}\right), 119.1\left(1 \mathrm{C}, C_{5}\right), 111.4(1 \mathrm{C}$, $\left.C_{4}\right), 35.9\left(1 \mathrm{C}, \mathrm{CH}_{3}\right)$. $\mathrm{MS}\left(\mathrm{FAB}^{+}\right): \mathrm{m} / \mathrm{z} 210\left[\mathrm{M}-\mathrm{Cl}^{-}\right]^{+}$.

\subsubsection{3-Mesityl-1-(quinolin-2-yl)-1H-imidazol-3-ium chloride (2)}

1-Mesitylimidazole (211 mg, $1.132 \mathrm{mmol})$ and 2-chloroquinoline (196 mg, $1.198 \mathrm{mmol})$ were stirred in a closed pressure tube at $170{ }^{\circ} \mathrm{C}$ for $12 \mathrm{~h}$. After cooling to room temperature, the crude product was dissolved in $\mathrm{CH}_{2} \mathrm{Cl}_{2}$ and precipitated with diethyl ether to afford a white solid, which was filtered and dried under vacuum (131 mg, 33\% yield). Anal. Calcd. For $\mathrm{C}_{21} \mathrm{H}_{20} \mathrm{~N}_{3} \mathrm{Cl}$ : C, 72.09; H, 5.76; N, 12.01. Found: C, 72.22; H, 5.82; N, 12.08. ${ }^{1} \mathrm{H}$ NMR (300 $\left.\mathrm{MHz} \mathrm{CDCl}_{3}\right) \delta 12.17\left(\mathrm{t}, J=1.5 \mathrm{~Hz}, 1 \mathrm{H}, H_{2}\right), 9.45\left(\mathrm{~d}, J=8.9 \mathrm{~Hz}, 1 \mathrm{H}, H_{8}\right), 9.07(\mathrm{t}, J=1.7 \mathrm{~Hz}$, $\left.1 \mathrm{H}, H_{5}\right), 8.60\left(\mathrm{~d}, J=8.9 \mathrm{~Hz}, 1 \mathrm{H}, H_{7}\right), 8.08\left(\mathrm{dd}, J=8.6,0.8 \mathrm{~Hz}, 1 \mathrm{H}, H_{13}\right), 7.98(\mathrm{dd}, J=8.4,0.8$ $\left.\mathrm{Hz}, 1 \mathrm{H}, H_{10}\right), 7.85$ (ddd, $\left.J=8.6,6.9,1.5 \mathrm{~Hz}, 1 \mathrm{H}, H_{12}\right), 7.68(\mathrm{ddd}, J=8.4,6.9,1.2 \mathrm{~Hz}, 1 \mathrm{H}$, $\left.H_{11}\right), 7.37\left(\mathrm{t}, J=1.7 \mathrm{~Hz}, 1 \mathrm{H}, H_{4}\right), 7.08$ (d, $\left.J=1.2 \mathrm{~Hz}, 2 \mathrm{H}, H_{M e s}\right), 2.38$ (s, 3H, CH $H_{3}, 2.25$ (s, $\left.6 \mathrm{H}, \mathrm{CH}_{3}\right) .{ }^{13} \mathrm{C}$ NMR $\left(101 \mathrm{MHz}, \mathrm{CDCl}_{3}\right) \delta 146.0\left(1 \mathrm{C}, \mathrm{C}_{6}\right), 144.9\left(1 \mathrm{C}, C_{14}\right), 141.8\left(1 \mathrm{C}, \mathrm{C}_{8}\right)$, 141.5 (1C, $\left.C_{M e s}\right), 137.8$ (1C, $\left.C_{2}\right), 134.0\left(2 \mathrm{C}, C_{M e s}\right), 131.3$ (1C, $\left.C_{12}\right), 130.7$ (1C, $\left.C_{M e s}\right), 130.0$ (2C, $\left.C_{M e s}\right), 128.7\left(1 \mathrm{C}, C_{13}\right), 128.5\left(1 \mathrm{C}, C_{9}\right), 128.2\left(1 \mathrm{C}, C_{10}\right), 128.1\left(1 \mathrm{C}, C_{11}\right), 123.9\left(1 \mathrm{C}, C_{7}\right)$, $119.9\left(1 \mathrm{C}, C_{5}\right), 114.1\left(1 \mathrm{C}, C_{4}\right), 21.1\left(1 \mathrm{C}, C_{M e s}\right), 17.9\left(2 \mathrm{C}, C_{M e s}\right) . \mathrm{HRMS}\left(\mathrm{ES}^{+}\right): \mathrm{m} / \mathrm{z}=$ $314.1657[\mathrm{M}-\mathrm{Cl}]^{+}$.

\subsubsection{3-(4-Methylthiophenyl)-1-(quinolin-2-yl)-1H-imidazol-3-ium chloride (3)}

1-(4-Methylthiophenyl)-1H-imidazole was synthetized according to a modified literature procedure. Imidazole (3.24 g, $47.57 \mathrm{mmol})$, 4-bromothioanisole (4.83 g, $23.78 \mathrm{mmol}), \mathrm{K}_{2} \mathrm{CO}_{3}$ (3.29 g, $23.78 \mathrm{mmol}$ ) and a catalytic amount of $\mathrm{CuSO}_{4}$ were stirred in a closed pressure tube at $205{ }^{\circ} \mathrm{C}$ for $10 \mathrm{~h}$. After cooling to room temperature, the crude product was extracted with $\mathrm{MeOH}$, filtered and evaporated to dryness. The resulting residue was purified by column chromatography on silica gel with a mixture of $\mathrm{CH}_{2} \mathrm{Cl}_{2}$ and methanol (90:10) as eluent to give 1-(4-methylthiophenyl)-1 $H$-imidazole as a yellow solid (3.99 g, 88\% yield). ${ }^{1} \mathrm{H}$ NMR (300 $\left.\mathrm{MHz}, \mathrm{CDCl}_{3}\right) \delta 7.93(\mathrm{~s}, 1 \mathrm{H}), 7.40-7.31(\mathrm{~m}, 4 \mathrm{H}), 7.28(\mathrm{~s}, 1 \mathrm{H}), 7.24(\mathrm{~s}, 1 \mathrm{H}), 2.54(\mathrm{~s}, 3 \mathrm{H})$ [25]. 1-(4-Methylthiophenyl)-1H-imidazole (500 mg, $26.28 \mathrm{mmol}$ ) and 2-chloroquinoline (456 mg, 
$27.86 \mathrm{mmol}$ ) were stirred in a closed pressure tube at $170{ }^{\circ} \mathrm{C}$ for $12 \mathrm{~h}$. After cooling to room temperature, the white solid was triturated with $\mathrm{CH}_{2} \mathrm{Cl}_{2}$, filtered, and dried under vacuum. (729 mg, 86\% yield). Anal. Calcd. For $\mathrm{C}_{19} \mathrm{H}_{16} \mathrm{~N}_{3} \mathrm{ClS}$ : C, 64.49; H, 4.56; N, 11.87. Found: C, 64.30; H, 4.62; N, 11.88. ${ }^{1} \mathrm{H}$ NMR (300 MHz, DMSO-d $) \delta 11.02\left(\mathrm{~s}, 1 \mathrm{H}, H_{2}\right), 8.95-8.82(\mathrm{~m}$, $\left.2 \mathrm{H}, H_{5}, H_{8}\right), 8.65\left(\mathrm{t}, J=2.0 \mathrm{~Hz}, 1 \mathrm{H}, H_{4}\right), 8.49\left(\mathrm{~d}, J=8.9 \mathrm{~Hz}, 1 \mathrm{H}, H_{7}\right), 8.23-8.07\left(\mathrm{~m}, 2 \mathrm{H}, H_{10}\right.$, $\left.H_{13}\right), 8.06-7.90\left(\mathrm{~m}, 3 \mathrm{H}, H_{S M e P h}, H_{12}\right), 7.78\left(\mathrm{ddd}, J=8.2,6.9,1.2 \mathrm{~Hz}, 1 \mathrm{H}, H_{11}\right), 7.56$ (d, 2H, $J$ $\left.=8.7 \mathrm{~Hz}, 2 \mathrm{H}, H_{S M e P h}\right), 2.59\left(\mathrm{~s}, 3 \mathrm{H}, H_{S M e P h}\right) .{ }^{13} \mathrm{C} \mathrm{NMR}\left(101 \mathrm{MHz}, \mathrm{DMSO}-d_{6}\right) \delta 145.9\left(1 \mathrm{C}, C_{6}\right)$, $145.7\left(1 \mathrm{C}, C_{14}\right), 141.8\left(1 \mathrm{C}, C_{S M e P h}\right), 141.7\left(1 \mathrm{C}, C_{8}\right), 135.2\left(1 \mathrm{C}, C_{2}\right), 132.2\left(1 \mathrm{C}, C_{12}\right), 131.8$ (1C, $\left.C_{S M e P h}\right), 128.8\left(1 \mathrm{C}, C_{13}\right), 128.8\left(1 \mathrm{C}, C_{10}\right), 128.5\left(1 \mathrm{C}, C_{9}\right), 128.3\left(1 \mathrm{C}, C_{11}\right), 127.1(2 \mathrm{C}$, $\left.C_{S M e P h}\right), 123.0\left(2 \mathrm{C}, C_{S M e P h}\right), 122.6\left(1 \mathrm{C}, C_{7}\right), 120.4\left(1 \mathrm{C}, C_{5}\right), 113.6\left(1 \mathrm{C}, C_{4}\right), 15.0\left(1 \mathrm{C}, C_{S M e P h}\right)$. HRMS (ES+): $\mathrm{m} / \mathrm{z}=318.1060[\mathrm{M}-\mathrm{Cl}]^{+}$.

\subsubsection{Preparation of complexes}

\subsubsection{Complex 6}

Under a nitrogen atmosphere and protection of the light, a Schlenk tube was charged with $1(76.7 \mathrm{mg}, 0.312 \mathrm{mmol})$ in $6 \mathrm{ml}$ of acetonitrile and $\mathrm{Ag}_{2} \mathrm{O}(72.3 \mathrm{mg}, 0.312 \mathrm{mmol})$. The reaction mixture was stirred at $40{ }^{\circ} \mathrm{C}$ for $24 \mathrm{~h}$. After that $\mathrm{Au}\left(\mathrm{SMe}_{2}\right) \mathrm{Cl}(110 \mathrm{mg}, 0.374 \mathrm{mmol})$ was added and the mixture was stirred for $4 \mathrm{~h}$. The solution was filtered through a pad of celite and the solvent removed under reduced pressure to give a pale yellow solid $(0.117 \mathrm{~g}$, $85 \%$ yield). Crystals suitable for $\mathrm{X}$-ray diffraction analysis were obtained by slow evaporation of an acetonitrile solution of 6. Anal. Calcd. For $\mathrm{C}_{13} \mathrm{H}_{11} \mathrm{~N}_{3} \mathrm{ClAu}$ : C, 35.35; H, 2.51; N, 9.51. Found: C, 35.22; H, 2.72; N, 9.48. ${ }^{1} \mathrm{H}$ NMR (400 MHz, $\left.\mathrm{CD}_{3} \mathrm{CN}\right) \delta 8.55(\mathrm{~d}, J=8.7 \mathrm{~Hz}, 1 \mathrm{H}$, $\left.H_{7}\right), 8.47\left(\mathrm{~d}, J=8.7 \mathrm{~Hz}, 1 \mathrm{H}, H_{8}\right), 8.14-8.03\left(\mathrm{~m}, 2 \mathrm{H}, H_{10}, H_{13}\right), 7.93\left(\mathrm{~d}, J=2.0 \mathrm{~Hz}, 1 \mathrm{H}, H_{5}\right)$, $7.88\left(\mathrm{ddd}, J=8.5,6.9,1.5 \mathrm{~Hz}, 1 \mathrm{H}, H_{12}\right), 7.71\left(\mathrm{ddd}, J=8.1,6.9,1.2 \mathrm{~Hz}, 1 \mathrm{H}, H_{11}\right), 7.39$ (d, $J=$ $\left.2.0 \mathrm{~Hz}, 1 \mathrm{H}, H_{4}\right), 3.97\left(\mathrm{~s}, 3 \mathrm{H}, \mathrm{CH}_{3}\right) .{ }^{13} \mathrm{C} \mathrm{NMR}\left(101 \mathrm{MHz}, \mathrm{CD}_{3} \mathrm{CN}\right) \delta 170.1\left(1 \mathrm{C}, C_{2}\right), 149.55$ (1C, $\left.C_{6}\right), 146.41$ (1C, $\left.C_{14}\right), 139.43$ (1C, $\left.C_{8}\right), 130.99$ (1C, $C_{12}$ ), 128.60 (1C, $\left.C_{13}\right), 128.05$ (1C, $\left.C_{10}\right), 127.80\left(1 \mathrm{C}, C_{9}\right), 127.45\left(1 \mathrm{C}, C_{11}\right), 123.18$ (1C, $\left.C_{7}\right), 120.56\left(1 \mathrm{C}, C_{5}\right), 116.10\left(1 \mathrm{C}, C_{4}\right)$, $38.77\left(1 \mathrm{C}, \mathrm{CH}_{3}\right)$. HRMS (ES+): $\mathrm{m} / \mathrm{z}=442.0385[\mathrm{M}+\mathrm{H}]^{+}$.

\subsubsection{Complex 7}

Under a nitrogen atmosphere, sodium acetate $(31 \mathrm{mg}, 0.377 \mathrm{mmol})$ was added to a mixture of $2(110 \mathrm{mg}, 0.314 \mathrm{mmol})$ and $\mathrm{Au}\left(\mathrm{SMe}_{2}\right) \mathrm{Cl}(46.3 \mathrm{mg}, 0.157 \mathrm{mmol})$ in dry DMF (3 mL) at $100{ }^{\circ} \mathrm{C}$. The mixture was then heated to $120^{\circ} \mathrm{C}$ and this temperature was maintained for $2 \mathrm{~h}$. After cooling to room temperature, $\mathrm{CH}_{2} \mathrm{Cl}_{2}(1 \mathrm{~mL})$ and $\mathrm{Et}_{2} \mathrm{O}(50 \mathrm{~mL})$ were added and the solution was kept at $-4{ }^{\circ} \mathrm{C}$ for $2 \mathrm{~h}$ to afford a white solid. After filtration, complex 7 was dried 
under vacuum (100 mg, 74\% yield). Crystals suitable for X-ray diffraction analysis were obtained by slow evaporation of a methanolic solution of 7. Anal. Calcd. For $\mathrm{C}_{42} \mathrm{H}_{38} \mathrm{~N}_{6} \mathrm{ClAu}$ : $\mathrm{C}, 58.71 ; \mathrm{H}, 4.46 ; \mathrm{N}, 9.78$. Found: C, 58.62; H, 4.42; N, 9.63. ${ }^{1} \mathrm{H} \mathrm{NMR}\left(300 \mathrm{MHz}, \mathrm{CD}_{3} \mathrm{OD}\right) \delta$ $8.29\left(\mathrm{~d}, J=2.0 \mathrm{~Hz}, 1 \mathrm{H}, H_{5}\right), 8.25\left(\mathrm{~d}, J=8.6 \mathrm{~Hz}, 1 \mathrm{H}, H_{8}\right), 8.04-7.88\left(\mathrm{~m}, 3 \mathrm{H}, H_{7}, H_{10}, H_{13}\right)$, $7.83-7.74\left(\mathrm{~m}, 1 \mathrm{H}, H_{12}\right), 7.66\left(\mathrm{ddd}, J=8.2,6.9,1.2 \mathrm{~Hz}, 1 \mathrm{H}, H_{11}\right), 7.52(\mathrm{~d}, J=2.0 \mathrm{~Hz}, 1 \mathrm{H}$, $\left.H_{4}\right), 6.91\left(\mathrm{~d}, J=1.2 \mathrm{~Hz}, 2 \mathrm{H}, H_{M e s}\right), 2.25$ (s, 3H, $\left.H_{M e s}\right), 1.96\left(\mathrm{~s}, 6 \mathrm{H}, H_{M e s}\right) .{ }^{13} \mathrm{C} \mathrm{NMR}(101$ $\left.\mathrm{MHz}, \mathrm{CD}_{3} \mathrm{OD}\right) \delta 181.4\left(1 \mathrm{C}, C_{2}\right), 147.4\left(1 \mathrm{C}, C_{6}\right), 144.7\left(1 \mathrm{C}, C_{14}\right), 138.1\left(1 \mathrm{C}, C_{8}\right), 138.0(1 \mathrm{C}$, $\left.C_{M e s}\right), 133.5$ (1C, $\left.C_{M e s}\right), 132.9$ (2C, $\left.C_{M e s}\right), 129.4$ (1C, $\left.C_{12}\right), 127.4$ (2C, $\left.C_{M e s}\right), 126.7\left(1 \mathrm{C}, C_{13}\right)$, $126.3\left(1 \mathrm{C}, C_{9}\right), 126.2\left(1 \mathrm{C}, C_{10}\right), 125.9\left(1 \mathrm{C}, C_{11}\right), 122.4\left(1 \mathrm{C}, C_{7}\right), 119.8\left(1 \mathrm{C}, C_{5}\right), 113.5(1 \mathrm{C}$, $\left.C_{4}\right), 18.3\left(1 \mathrm{C}, C_{M e s}\right), 14.9\left(2 \mathrm{C}, C_{M e s}\right)$. HRMS $\left(\mathrm{ES}^{+}\right): m / z=831.1658[\mathrm{M}-\mathrm{H}]^{+}$.

\subsubsection{Complex 8}

Under a nitrogen atmosphere, sodium acetate $(32.83 \mathrm{mg}, 0.400 \mathrm{mmol})$ was added to a mixture of 3 (118 mg, $0.334 \mathrm{mmol})$ and $\mathrm{Au}\left(\mathrm{SMe}_{2}\right) \mathrm{Cl}(49 \mathrm{mg}, 0.167 \mathrm{mmol})$ in dry DMF (3 $\mathrm{mL}$ ) at $100{ }^{\circ} \mathrm{C}$. The mixture was then heated to $120{ }^{\circ} \mathrm{C}$ and this temperature was maintained for $2 \mathrm{~h}$. After cooling to room temperature, $\mathrm{CH}_{2} \mathrm{Cl}_{2}(1 \mathrm{~mL})$ and $\mathrm{Et}_{2} \mathrm{O}(10 \mathrm{~mL})$ were added and the solution was kept at $-4{ }^{\circ} \mathrm{C}$ for $2 \mathrm{~h}$ to afford a beige solid. After filtration, complex 8 was dried under vacuum (99 mg, 74\% yield). Anal. Calcd. For $\mathrm{C}_{38} \mathrm{H}_{30} \mathrm{~N}_{6} \mathrm{ClS}_{2} \mathrm{Au}$ : C, 52.63; H, 3.49; N, 9.69. Found: C, 52.72; H, 3.62; N, 9.74. ${ }^{1} \mathrm{H}$ NMR (400 MHz, $\left.\mathrm{CD}_{3} \mathrm{OD}\right) \delta 8.22$ (d, $J=$ $\left.2.0 \mathrm{~Hz}, 1 \mathrm{H}, H_{5}\right), 8.14-8.04\left(\mathrm{~m}, 2 \mathrm{H}, H_{8}, H_{13}\right), 7.90\left(\mathrm{~d}, J=8.5 \mathrm{~Hz}, 1 \mathrm{H}, H_{7}\right), 7.86-7.80(\mathrm{~m}$, $\left.2 \mathrm{H}, H_{10}, H_{4}\right), 7.80-7.72\left(\mathrm{~m}, 1 \mathrm{H}, H_{12}\right), 7.66-7.56\left(\mathrm{~m}, 3 \mathrm{H}, H_{S M e P h}, H_{11}\right), 7.13(\mathrm{~d}, J=8.6 \mathrm{~Hz}$, $\left.2 \mathrm{H}, H_{S M e P h}\right), 2.46$ (s, $\left.1 \mathrm{H}, H_{S M e P h}\right) .{ }^{13} \mathrm{C}$ NMR $\left(101 \mathrm{MHz}, \mathrm{CD}_{3} \mathrm{OD}\right) \delta 180.8\left(1 \mathrm{C}, C_{2}\right), 149.2(1 \mathrm{C}$, $\left.C_{6}\right), 146.2\left(1 \mathrm{C}, C_{14}\right), 141.0\left(1 \mathrm{C}, C_{S M e P h}\right), 139.6\left(1 \mathrm{C}, C_{8}\right), 136.0\left(1 \mathrm{C}, C_{S M e P h}\right), 131.2\left(1 \mathrm{C}, C_{12}\right)$, 128.4 (1C, $\left.C_{13}\right), 128.0$ (1C, $\left.C_{10}\right), 127.8$ (1C, $\left.C_{9}\right), 127.7$ (1C, $\left.C_{11}\right), 126.0$ (2C, $\left.C_{S M e P h}\right), 125.4$ (2C, $\left.C_{S M e P h}\right), 123.8\left(1 \mathrm{C}, C_{7}\right), 122.0\left(1 \mathrm{C}, C_{5}\right), 115.9$ (1C, $\left.C_{4}\right), 14.1$ (1C, $\left.C_{S M e P h}\right)$,). HRMS $\left(\mathrm{ES}^{+}\right): m / z=823.2840[\mathrm{M}-\mathrm{H}]^{+}$.

\subsubsection{Crystallographic data for 4-6}

All data were collected at low temperature using oil-coated shock-cooled crystals on a Bruker-AXS APEX II diffractometer with MoK $\alpha$ radiation $(\lambda=0.71073 \AA)$. The structures were solved by direct methods [28] and all non hydrogen atoms were refined anisotropically using the least-squares method on $F^{2}$ [29].

6: $\mathrm{C}_{13} \mathrm{H}_{11} \mathrm{AuClN}_{3}, \mathrm{Mr}=441.66$, crystal size $=0.40 \times 0.30 \times 0.30 \mathrm{~mm}^{3}$, monoclinic, space group $P 2_{1} / n, a=3.983(2) \AA, b=12.613(4) \AA, c=24.744(8) \AA, \beta=91.35(2)^{\circ}, \mathrm{V}=1242.8(7)$ 
$\AA^{3}, \mathrm{Z}=4, \mathrm{~T}=173(2) \mathrm{K}, 9449$ reflections collected, 1784 unique reflections $\left(\mathrm{R}_{\text {int }}=0.1715\right)$, $\mathrm{R} 1=0.0659, \mathrm{wR} 2=0.1471[\mathrm{I}>2 \sigma(\mathrm{I})], \mathrm{R} 1=0.1213, \mathrm{wR} 2=0.1732$ (all data), residual electron density $=3.189 \mathrm{e}^{-3}$.

7: $\mathrm{C}_{42} \mathrm{H}_{39} \mathrm{AuCl}_{2} \mathrm{~N}_{6}, \mathrm{Mr}=895.66$, crystal size $=0.20 \times 0.05 \times 0.05 \mathrm{~mm}^{3}$, orthorhombic, space group $P 2{ }_{1}{ }_{2}{ }_{1}{ }_{1}, a=15.1793(4) \AA, b=17.4742(5) \AA, c=29.2211(8) \AA, \mathrm{V}=7750.8(4)$ $\AA^{3}, Z=8, T=173(2) \mathrm{K}, 76886$ reflections collected, 14933 unique reflections $\left(\mathrm{R}_{\text {int }}=0.0439\right)$, $\mathrm{R} 1=0.0302, \mathrm{wR} 2=0.0533[\mathrm{I}>2 \sigma(\mathrm{I})], \mathrm{R} 1=0.0466, \mathrm{wR} 2=0.0573$ (all data), residual electron density $=1.516$ e $\AA^{-3}$.

CCDC-1040256 (6) and CCDC-1040257 (7) contain the supplementary crystallographic data. These data can be obtained free of charge from The Cambridge Crystallographic Data Centre via www.ccdc.cam.ac.uk/data_request/cif.

\subsubsection{Antileishmanial evaluation}

Leishmania species used in this study were Leishmania infantum MHOM/MA/67/ITMAP263 (CNR Leishmania, Montpellier, France) expressing luciferase activity.

\subsubsection{Antileishmanial activity on promastigotes}

The effects of the tested compounds on the growth of Leishmania infantum promastigotes were assessed by Luciferase Assay. Briefly, promastigotes in log-phase in RPMI 1640 medium supplemented with $10 \%$ fetal calf serum (FCS), $2 \mathrm{mM}$ L-glutamine and antibiotics (100U/mL penicillin, $100 \mu \mathrm{g} / \mathrm{mL}$ streptomycin and $50 \mu \mathrm{g} / \mathrm{mL}$ geneticin), were incubated at an average density of $10^{6}$ parasites $/ \mathrm{mL}$ in sterile 96 -well plates with various concentrations of compounds dissolved in DMSO (final concentration less than $0.5 \% \mathrm{v} / \mathrm{v}$ ), in duplicate. Appropriate controls treated by DMSO, amphotericin B, miltefosine and pentamidine (reference drugs purchased from Sigma Aldrich) were added to each set of experiments. After a $72 \mathrm{~h}$ incubation period at $24{ }^{\circ} \mathrm{C}$, each plate-well was then microscope-examined for detecting possible precipitate formation. To estimate the luciferase activity of promastigotes, $80 \mu \mathrm{l}$ of each well are transferred in white 96-well plates, Steady Glow reagent (Promega) was added according to manufacter's instructions, and plates were incubated for $2 \mathrm{~min}$.. The luminescence was measured in Microbeta Luminescence Counter (PerkinElmer). Inhibitory concentration $50 \%\left(\mathrm{IC}_{50}\right)$ was defined as the concentration of drug required to inhibit by $50 \%$ the metabolic activity of Leishmania infantum promastigotes compared to the control. $\mathrm{IC}_{50}$ were calculated by non-linear regression analysis processed on dose-response curves, using 
TableCurve 2D V5 software. IC $_{50}$ values represent the mean value calculated from three independent experiments.

\subsubsection{Antileishmanial activity on intracellular amastigotes}

The effects of the tested compounds on the growth of $L$. infantum intracellular amastigotes were assessed in the following way. $100 \mu \mathrm{L}$ of J774A.1 cells were seeded 96-well plates at an average density of $1.10^{5}$ cells $/ \mathrm{mL}$ and incubated for $24 \mathrm{~h}$ at $37{ }^{\circ} \mathrm{C}$ and $5 \% \mathrm{CO}_{2}$. L. Infantum promastigotes were centrifuged at $900 \mathrm{~g}$ for $10 \mathrm{~min}$ and the supernatant replaced by the same volume of RPMI 1640 complete medium at pH 5.4 and incubated for $24 \mathrm{~h}$ at $27{ }^{\circ} \mathrm{C}$. Then, half of the macrophages medium was removed, J774A.1 cells were then infected by $100 \mu 1$ of acidified promastigotes at an average density of $1.10^{6}$ cells $/ \mathrm{mL}$ (10:1 ratio) and plates incubated for $24 \mathrm{~h}$ at $37{ }^{\circ} \mathrm{C}$ and $5 \% \mathrm{CO}_{2}$. Half of the infected macrophages medium was removed and medium containing various concentrations of tested-compounds was added (final DMSO concentration being inferior to $0.5 \% \mathrm{v} / \mathrm{v}$ ) in duplicate. Appropriate controls treated with or without solvent (DMSO), and various concentrations of amphotericin B, miltefosine and pentamidine were added to each set of experiments. After $120 \mathrm{~h}$ incubation at $37{ }^{\circ} \mathrm{C}$ and $5 \% \mathrm{CO}_{2}, 100 \mu \mathrm{l}$ of well supernatant was removed and Steady Glow reagent (Promega) was added according to manufacter's instructions. Plates were incubated for $3 \mathrm{~min}$. $100 \mu \mathrm{L}$ of each well were transferred in white 96-well plates and the luminescence was measured in Microbeta Luminescence Counter (PerkinElmer). Inhibitory concentration 50\% ( $\left.\mathrm{IC}_{50}\right)$ was defined as the concentration of drug required to inhibit by $50 \%$ the metabolic activity of $L$. Infantum intracellular amastigotes compared to the control. IC 50 were calculated by non-linear regression analysis processed on dose-response curves, using TableCurve $2 \mathrm{D}$ V5 software. $\mathrm{IC}_{50}$ values represent the mean value calculated from three independent experiments.

\subsubsection{Cytotoxicity evaluation}

The evaluation of the tested molecules cytotoxicity by MTT assay on the J774A.1 cell line (mouse macrophage cell line, Sigma-Aldrich) was done according to Mosmann with slight modifications [30]. Briefly, cells $\left(5.10^{4}\right.$ cells $\left./ \mathrm{mL}\right)$ in $100 \mu \mathrm{L}$ of complete medium, [RPMI 1640 supplemented with $10 \%$ fetal calf serum (FCS), $2 \mathrm{mM}$ L-glutamine and antibiotics $(100 \mathrm{U} / \mathrm{mL}$ penicillin and $100 \mu \mathrm{g} / \mathrm{mL}$ streptomycin)] were seeded into each well of 96-well plates and incubated at $37{ }^{\circ} \mathrm{C}$ and $5 \% \mathrm{CO}_{2}$. After a $24 \mathrm{~h}$ incubation, $100 \mu \mathrm{L}$ of medium with various product concentrations and appropriate controls were added and the plates were incubated for $72 \mathrm{~h}$ at 37 
${ }^{\circ} \mathrm{C}$ and $5 \% \mathrm{CO}_{2}$. Each plate-well was then microscope-examined for detecting possible precipitate formation before the medium was aspirated from the wells. $100 \mu \mathrm{L}$ of MTT solution $(0.5 \mathrm{mg} / \mathrm{mL}$ in RPMI) were then added to each well. Cells were incubated for $2 \mathrm{~h}$ at $37{ }^{\circ} \mathrm{C}$ and $5 \% \mathrm{CO}_{2}$. After this time, the MTT solution was removed and DMSO $(100 \mu \mathrm{L})$ was added to dissolve the resulting formazan crystals. Plates were shaken vigorously (300 rpm) for $5 \mathrm{~min}$. The absorbance was measured at $570 \mathrm{~nm}$ with a microplate spectrophotometer (Eon BioTek). DMSO was used as blank and doxorubicin (purchased from Sigma Aldrich) as positive control. $\mathrm{CC}_{50}$ were calculated by non-linear regression analysis processed on dose-response curves, using TableCurve 2D V5 software. $\mathrm{CC}_{50}$ values represent the mean value calculated from three independent experiments.

Table 1. In vitro antileishmanial activity and cytotoxicity of compounds 1-9. 


\section{References}

[1] World Health Organization: http://whqlibdoc.who.int/trs/WHO_TRS_949_eng.pdf.

[2] World Health Organization:

http://www.who.int/leishmaniasis/resources/Leishmaniasis worldwide epidemiological and drug access update.pdf.

[3] C.B. Palatnik-de-Souza, Front Immunol. 3 (2012) 69.

[4] K.J. Evans, L. Kedzierski, J. Trop. Med. (2012) 892817 doi: 10.1155/2012/892817.

[5] K.A. Reynolds, W.A. Loughlin, D.J. Young, Mini. Rev. Med. Chem. 13(5) (2013) 730-743.

[6] S. Sundar, J. Chakravarty, Expert. Opin. Investig. Drugs 24(1) (2015) 43-59.

[7] J.V. Richard, K.A. Werbovetz, Curr. Opin. Chem. Biol. 14(4) (2010) 447-455.

[8] K. Jain, N.K. Jain, Drug. Discov. Today 18 (2013) 23-24.

[9] C. Castera-Ducros, L. Paloque, P. Verhaeghe, M. Casanova, C. Cantelli, S. Hutter, F. Tanguy, M. Laget, V. Remusat, A. Dumètre, M.D. Crozet, A. Cohen, P. Rathelot, P. Vanelle, N., Azas, Biorg. Med. Chem. 15;21(22) (2013) 7155-7164.

[10] L. Paloque, P. Verhaeghe, M. Casanova, C. Castera-Ducros, A. Dumètre, L. Mbatchi, S. Hutter, M. Kraiem-M'rabet, M. Laget, V. Remusat, S. Rault, P. Rathelot, N. Azas, P. Vanelle, Eur. J. Med. Chem. 54 (2012) 75-86.

[11] H. Hussain,, A. Al-Harrasi, A. Al-Rawahi, I.R. Green, S. Gibbons, Chem. Rev. 114 (2014) 10369-10428.

[12] B. Rosenberg, L. Van Camp, T. Krigas, Nature 205 (1965) 698-699.

[13] B. Rosenberg, L. Van Camp, J.E. Trosko, V.H. Mansour, Nature 222 (1969) 385-386.

[14] E. Alessio, Bioinorganic Medicinal Chemistry, Wiley-VCH Verlag \& Co., Germany 2011.

[15] N. Mbongo, P.M. Loiseau, F. Lawrence, C. Bories, G. Craciunescu, M. Robert-Gero, Parasitol. Res. 83 (1997) 515-517.

[16] N. Navarro, G. Visbal, E. Marchán, in: J.M. Pérez Martin (Ed.), Programmed Cell Death in Protozoa, Landes Bioscience and Springer., New York, 2008, pp.59-73.

[17] A.B. Caballero, J.M. Salas, M. Sánchez-Moreno, in: Metal-based Therapeutics for Leishmaniasis; 2014; pp.1-28.

[18] A. Tahghighi, J. Organomet. Chem. 770 (2014) 51-60.

[19] M. Navarro, Coord. Chem. Rev. 253 (2009) 1619-1626.

[20] C. Hemmert, A. Fabié, A. Fabre, F. Benoit-Vical, H. Gornitzka, Eur. J. Med. Chem. 60 (2013) 64-75.

[21] L. Boselli, I. Ader, M. Carraz, C. Hemmert, O. Cuvillier, H. Gornitzka, Eur. J. Med. Chem. 85 (2014) 87-94.

[22] J.C.Y. Lin, R.T.W. Huang, C.S. Lee, A. Bhattcharyya, W.S. Hwang, I.J.B. Lin, Chem. Rev. 109 (2009) 3561-3598. 
[23] A. Ilari, P. Baiocco, L. Messori, A. Fiorillo, A. Boffi, M. Gramiccia, T. Di Muccio, G. Colotti, Amino Acids 42 (2012) 803-811.

[24] M. Navarro, C. Hernández, I. Colmenares, P. Hernández, M. Fernández, A. Sierraalta, E. Marchán, J. Inorg. Biochem. 101 (2007) 111-116.

[25] M. Vieites, P. Smircich, L. Guggeri, E. Marchán, A. Gómez-Barrio, M. Navarro, B. Garat, D. Gambino, J. Inorg. Biochem. 103 (2009) 1300-1306.

[26] T. Strassner, Y. Unger, A. Zeller, PCT Int. Appl. (2008), WO 2008000726 A1 20080103.

[27] F. Bellina, S. Cauteruccio, L. Mannina, R. Rossi, S. Viel, J. Org. Chem. 70 (2005) 3997-4005.

[28] G. M. Sheldrick, Acta Crystallogr. A46 (1990) 467-473.

[29] G. M. Sheldrick, Acta Crystallogr. A64 (2008) 112-122.

[30] T. Mosmann, J. Immunol. Methods 65(1-2) (1983) 55-63. 
List of Schemes, Figures and Table.

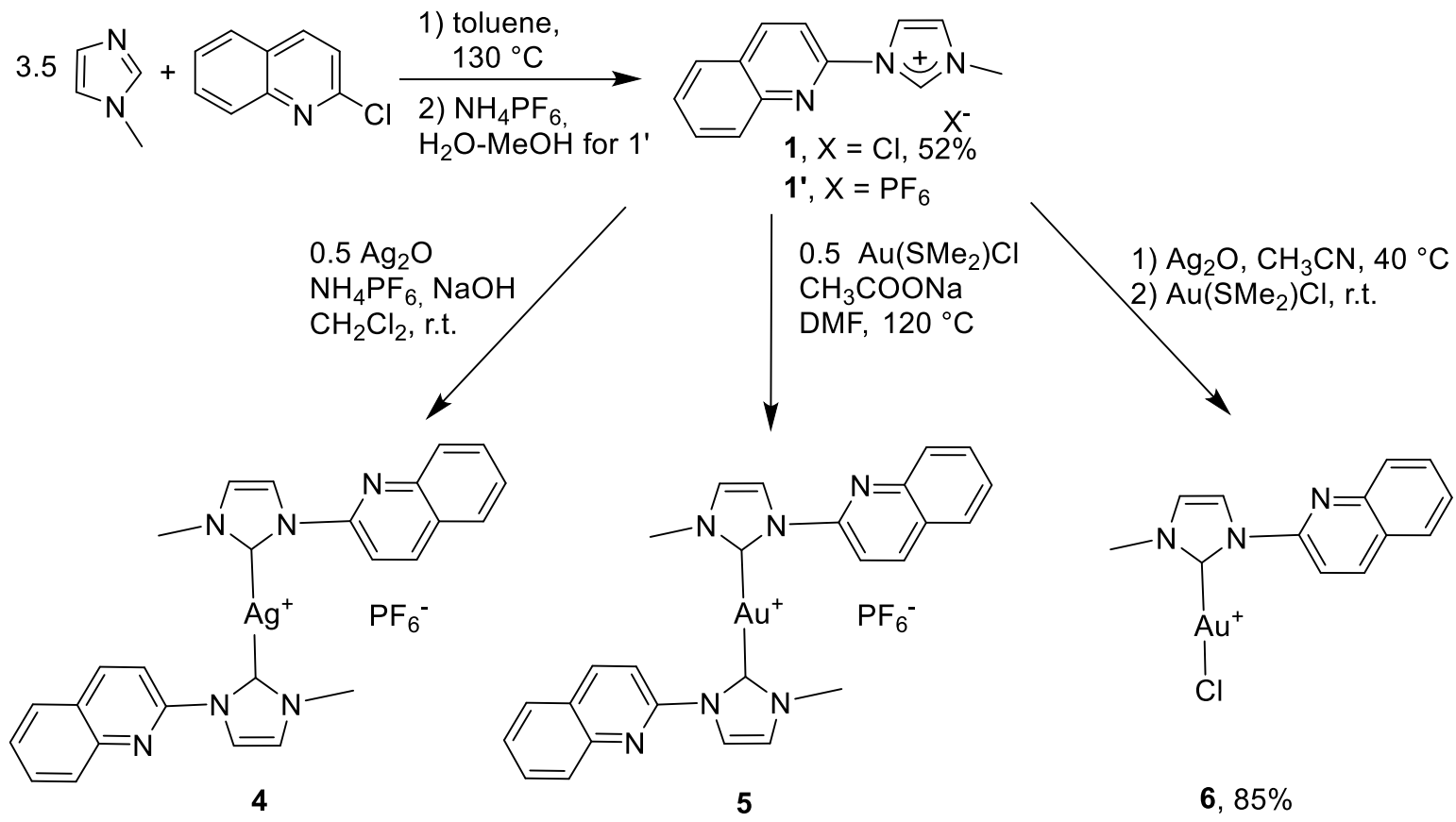

Scheme 1. Synthesis of imidazoliums salts 1 and 1' and silver(I) bis(NHC) (4), gold(I) bis(NHC) (5)and gold(I) NHC (6) complexes. 

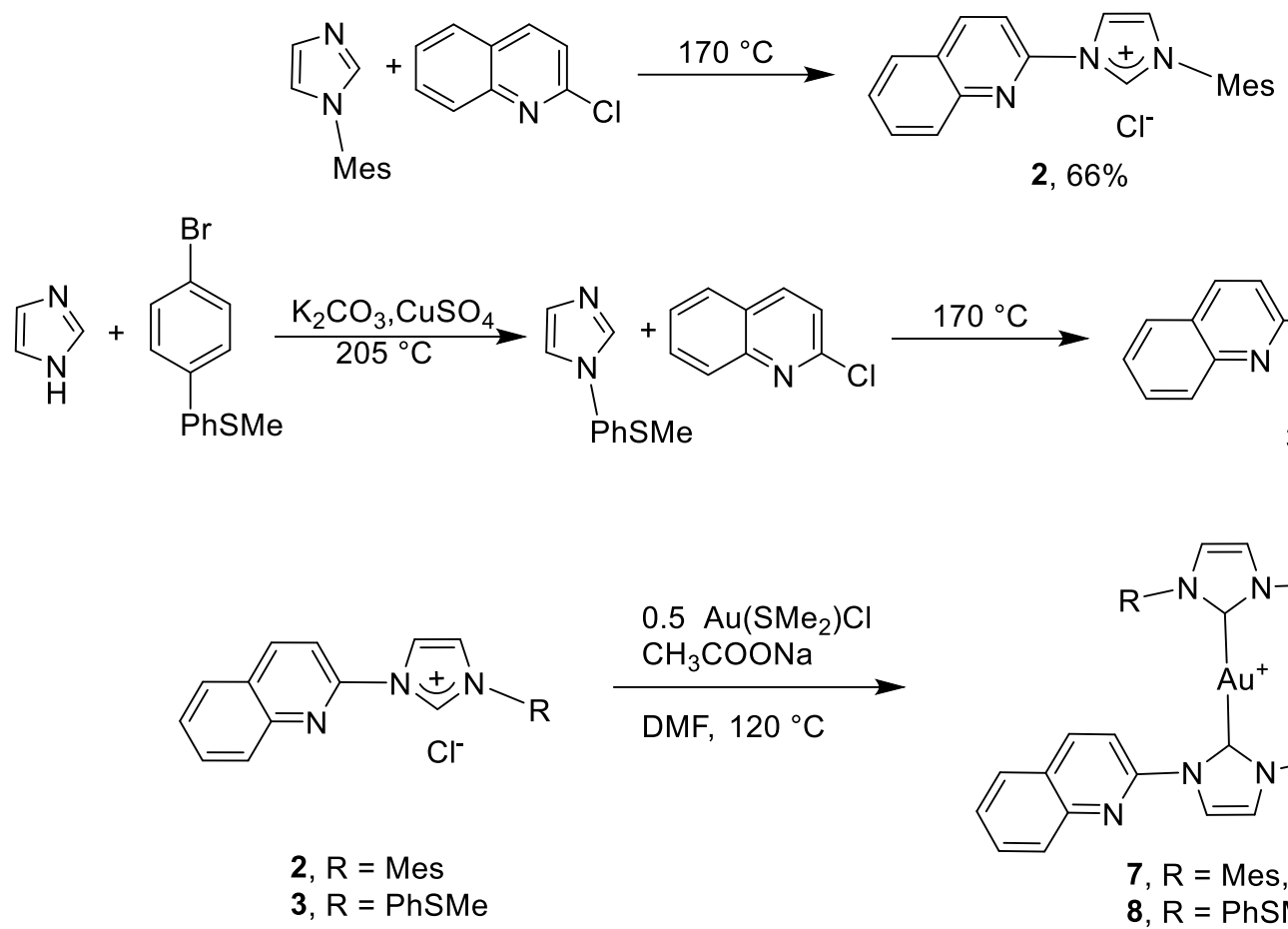

$\stackrel{170^{\circ} \mathrm{C}}{\longrightarrow}$

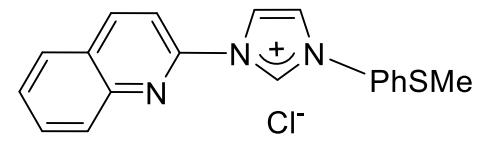

3, $86 \%$

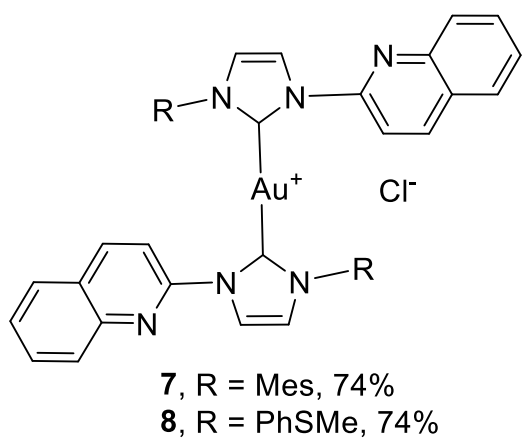

Scheme 2. Synthesis of imidazoliums salts $\mathbf{2}$ and $\mathbf{3}$ and gold(I) bis (NHC) complexes $\mathbf{7}$ and $\mathbf{8}$. 


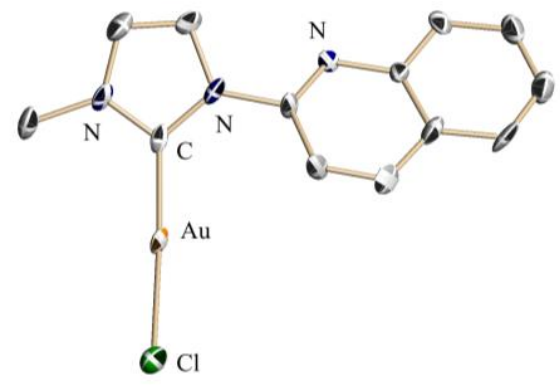

Figure 1: Crystal structure of 6 depicted at 50\% level. Hydrogen atoms have been omitted for clarity. Selected bond lengths $[\AA]$ and angles $\left[{ }^{\circ}\right]$ : Au-C 1.96(2), Au-Cl 2.28(1), C-Au-Cl 177.3(6).

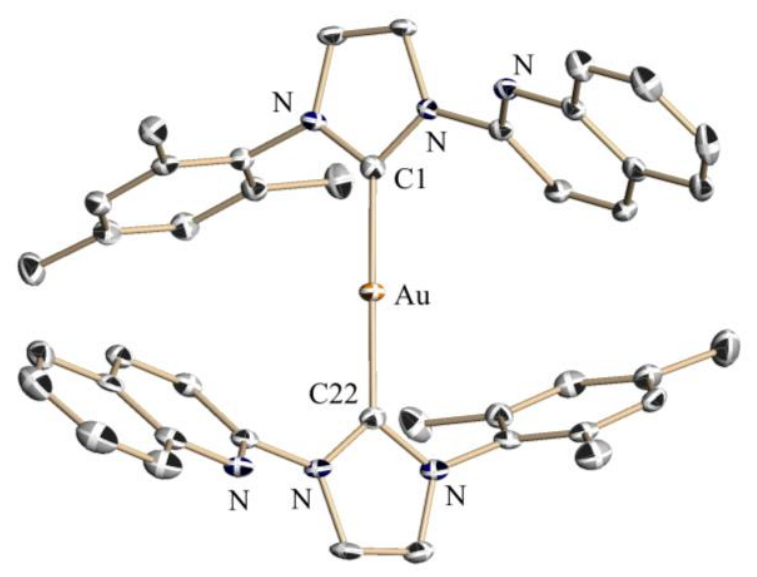

Figure 2: Crystal structure of the cationic part of 7 depicted at 30\% level. Non-coordinating anions and hydrogen atoms have been omitted for clarity. Selected bond lengths $[\AA]$ and angles [ ${ }^{\circ}$ ]: Au-C1 1.997(6), Au-C22 2.016(6), C1-Au-C22 178.9(2). 

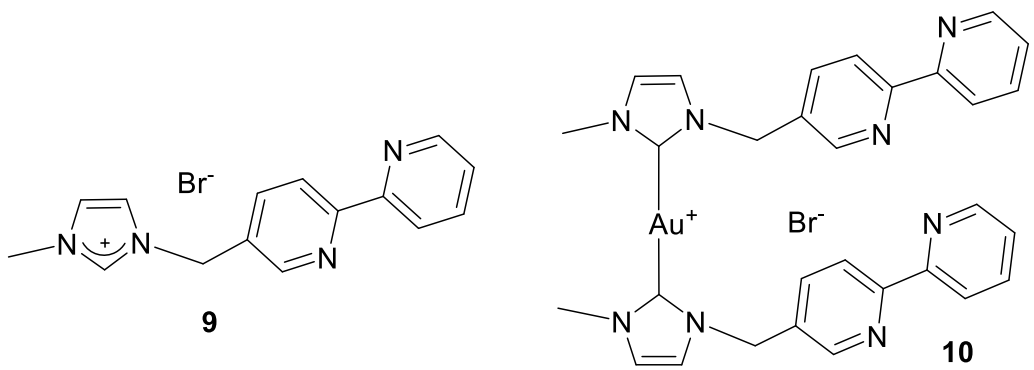

Figure 3. Compounds $\mathbf{9}$ and $\mathbf{1 0}$ also used in this study.
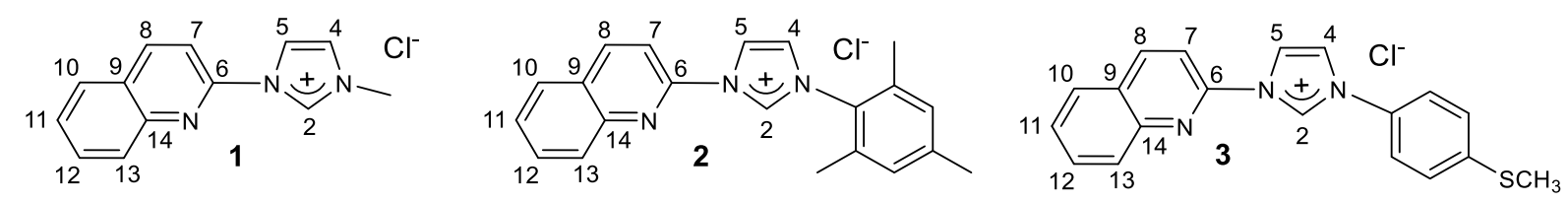

Scheme 3. Numbering of $\mathrm{H}\left({ }^{1} \mathrm{H}\right.$ NMR) and $\mathrm{C}\left({ }^{13} \mathrm{C}\right.$ NMR). These notations are used in the following experimental section. 
Table 1. In vitro antileishmanial activity and cytotoxicity of compounds 1-9.

\begin{tabular}{|c|c|c|c|c|c|}
\hline \multirow[t]{2}{*}{ Compound } & $\begin{array}{c}\text { L. infantum } \\
\text { promastigotes }\end{array}$ & J774A.1 & Selectivity index Pro & $\begin{array}{c}\text { L. infantum } \\
\text { intracellular amastigotes }\end{array}$ & Selectivity index Ama \\
\hline & $\mathrm{IC}_{50}(\mu \mathrm{M})^{\mathrm{a}}$ & $\operatorname{CC}_{50}(\mu M)^{a}$ & $\mathrm{CC}_{50} / \mathrm{IC}_{50}$ (Pro) & $\operatorname{IC}_{50}(\mu \mathrm{M})^{\mathrm{a}}$ & $\mathrm{CC}_{50} / \mathrm{IC}_{50}$ (Ama) \\
\hline 1 & $82.82 \pm 18.46$ & $48.36 \pm 16.72$ & 0.58 & - & - \\
\hline 1 ' & $>100$ & - & - & - & - \\
\hline 2 & $9.81 \pm 1.54$ & $0.92 \pm 0.08$ & 0.09 & - & - \\
\hline 3 & $11.96 \pm 4.22$ & $5.17 \pm 0.86$ & 0.43 & - & - \\
\hline 4 & $9.37 \pm 0.69$ & $15.13 \pm 2.37$ & 1.61 & - & - \\
\hline 5 & $0.39 \pm 0.14$ & $2.06 \pm 0.16$ & 5.33 & $0.40 \pm 0.23$ & 5.19 \\
\hline 6 & $1.53 \pm 0.62$ & $9.45 \pm 0.42$ & 6.19 & $0.96 \pm 0.55$ & 9.84 \\
\hline 7 & $0.42 \pm 0.13$ & $0.26 \pm 0.08$ & 0.61 & - & - \\
\hline 8 & $0.43 \pm 0.26$ & $1.29 \pm 0.45$ & 3.02 & $0.24 \pm 0.06$ & 5.45 \\
\hline 9 & $>100$ & - & - & - & - \\
\hline 10 & $1.86 \pm 0.22$ & $2.89 \pm 0.83$ & 1.56 & - & - \\
\hline Amphotericin $\mathbf{B}^{\mathbf{b}}$ & $0.04 \pm 0.03$ & $3.28 \pm 1.41$ & 79.92 & $0.07 \pm 0.03$ & 49.86 \\
\hline Miltefosine $^{b}$ & $8.83 \pm 2.77$ & $155.63 \pm 15,25$ & 17.63 & $4.17 \pm 2.58$ & 37.32 \\
\hline Pentamidine $^{b}$ & $0.51 \pm 0.28$ & $0.53 \pm 0.57$ & 1.04 & - & - \\
\hline Doxorubicin $^{\text {a }}$ & - & $0.08 \pm 0.03$ & - & - & - \\
\hline
\end{tabular}

${ }^{a}$ Mean of three independent experiments

b Amphotericin B, Miltefosine and Pentamidine were used as antileishmanial compounds of reference.

${ }^{\mathrm{c}}$ Doxorubicin was used as positive control of cytotoxicity. 
